\title{
A INCONSTITUCIONALIDADE DA RELATIVIZAÇÃO DA COISA JULGADA INCONSTITUCIONAL. UMA ANÁLISE DO PARÁGRAFO 12 DO ARTIGO 525 DO CPC/15
}

\author{
THE UNCONSTITUTIONALITY OF THE "RELATIVIZATION" OF RES \\ JUDICATA UNCONSTITUTIONAL. AN ANALYSIS OF PARAGRAPH 12 OF \\ ARTICLE 525 OF THE CPC / 15
}

\author{
${ }^{1}$ Raniel Fernandes de Ávila \\ 2 João Paulo Barbosa Lyra
}

\section{RESUMO}

O presente trabalho analisa o cabimento (ou não) do entendimento doutrinário acerca da possibilidade de relativizar-se a coisa julgada tida por inconstitucional. Para tanto, demonstra o Direito Positivo como objeto cultural arraigado de valores cujo escopo é a regulamentação da ação humana. Por esse prisma, pelo fato de o direito ter ínsito o fundamento do deôntico (dever-ser), o princípio da segurança jurídica tem relevância premente no sistema do direito positivo. Sob a perspectiva da teoria do direito, é que se analisa a tese de relativizar a coisa julgada, em cotejo ao parágrafo 12 do artigo 525 do Código de Processo Civil de 2015.

Palavras-chave: Direito positivo, Relativização da coisa julgada, Coisa julgada inconstitucional

\begin{abstract}
This paper analyzes the appropriateness (or not) of doctrinal understanding about the possibility of "relativize up" res judicata taken by unconstitutional. To do so, demonstrates the positive law as ingrained cultural object values whose scope is the regulation of human action. From this perspective, the fact that the right to have ínsito the foundation of deontic (must-be), the principle of legal certainty has urgent relevance in the positive law system. From the perspective of legal theory, it is that it examines the theory of relativity res judicata in collation to paragraph 12 of Article 525 of the Civil Procedure Code of 2015.
\end{abstract}

Keywords/Palabras-claves/Mots-clés: Positive law, Relativity of res judicator, Res judicata unconstitutional

1 Mestrando em Direito Processual Civil pela Universidade Federal do Espírito Santo. Universidade Federal do Espírito Santo - UFES, Espírito Santo. Brasil - E-mail: raniel.f.a@gmail.com

2 Mestrando em Direito Processual Civil pela Universidade Federal do Espírito Santo. Universidade Federal do Espírito Santo - UFES, Espírito Santo. Brasil - E-mail: joaopaulo.lyra@me.com 


\title{
INTRODUÇÃO
}

O descompasso metodológico ${ }^{1}$ de abordagem do direito, por parte dos juristas, traz grandes prejuízos ao sistema do direito positivo, além de debates estéreis ${ }^{2}$ em torno do seu objeto único de estudo: o direito positivo. Criam-se expressões destituídas de referencialidade ao ponto de estudo que acabam por gerar ao operador do direito tergiversações das mais diversas. Não fosse isso suficiente, o legislador, por meio de sua linguagem técnica e em esmagadoras vezes destituído de saber jurídico ${ }^{3}$ injeta no sistema jurídico enunciados que não condizem com a melhor interpretação sistemática.

A proposta de "relativização" da coisa julgada material tida por "inconstitucional"4 capitaneada por autores de escol como Cândido Rangel Dinamarco, José Delgado, Humberto Teodoro Junior, Carlos Valder do Nascimento, Ivo Dantas, entre outros, trouxe algumas discordâncias doutrinárias ${ }^{5}$ com a sistemática jurídica. A começar pelo traço terminológico das expressões "relativizar" e "coisa julgada inconstitucional". Ora, pondera Barbosa Moreira ${ }^{6}$

\begin{abstract}
quando se afirma que algo deve ser relativizado, logicamente se dá a entender que se está enxergando nesse algo um absoluto: não faz sentido que se pretenda "relativizar" o que já é relativo. Ora, até a mais superficial mirada ao ordenamento jurídico brasileiro mostra que nele está longe de ser absoluto o valor da coisa julgada material. (...) está ai no campo civil, a ação rescisória $[\ldots]$.
\end{abstract}

\footnotetext{
1 Para esclarecimentos acerca da necessidade metodológica para empreender um estudo do direito psitivo, analisar a obra Fontes do Direito Tributário, ed. Max Limonad, 2001 de Tárek Moysés Moussallem. À fl. 35, o mestre capixaba conclui: "Isso não significa que o cientista dogmático não deve estar preocupado com a "justiça". Como ser humano que é, encontra-se necessariamente inserido no mundo cultural e, por consequência, imbuído de valores. Ocorre que o valor jurídico é posto pelo ordenamento e não pelo sujeito cognoscente. Por isso, como dogmático, não lhe caberá emitir juízos de como deve ser o dever-ser.

2 Essa expressão é de MOUSSALlEM, Tárek Moysés. em artigo publicado intitulado: Função das Súmulas e Critérios para Aferir sua Validade, vigência e aplicabilidade. Artigo inédito.

3 Ocioso lembrar que pelo fato de o Brasil ser uma democracia, nada mais natural que seus governantes e seus legisladores sejam profissionais dos mais diversos ramos, como engenheiros, médicos, pedreiros, enfermeiros, etc, razão essa que justifica a ausência de saber jurídico apurado quando da feitura das leis. Nada mais natural.

4 Sobre o assunto verificar a obra coletiva Coisa Julgada Inconstitucional. organizada por Carlos Valder do Nascimento, Rio de Janeiro, 3 ed., 2004.

5 Para citar alguns: MOREIRA Barbosa. Considerações sobre a Chamada "Relativização da Coisa Julgada Material, in. Temas de Direito Processual (nona série), Ed. Saraiva, 2007; Nelson Nery Junior, Coisa Julgada e o Estado Democrático de direito, in. Revista Forense, v. 375; SILVA, Ovídio. A. Batista. Coisa Julgada Relativa? In, volume coletivo coordenado por Fredie Diddier Jr. Editora Podium,

2008. Ainda nessa obra coletiva, GÓES, Gisele com o artigo denominado "A "Relativização"da Coisa Julgada: Exame Crítico (Exposição de um Ponto de Vista Contrário) e MARINONI, Luiz Guilherme. O Princípio da Segurança dos Atos Jurisdicionais (A Questão da Relativização da Coisa Julgada Material).

6 MOREIRA, Barbosa. Considerações sobre a Chamada "Relativização" da Coisa Julgada Material, in

Temas de Direito Processual (nona série), p. 235-236
} 
Ainda, nesse passo, se a coisa julgada encontra guarida expressa no texto constitucional (XXXVI ${ }^{7}$, art. 5), como então considerá-la inconstitucional? Não se desconhece a tese soerguida pelos fautores da relativização no sentido de que tal dispositivo volta-se somente ao Poder Legislativo ${ }^{8}$, porém tal consideração é equivocada por desvelar uma interpretação meramente literal do texto; é necessária uma interpretação sistemática do direito positivo.

Assim, seria possível a relativização da coisa julga inconstitucional? Esta a problemática a que se almeja responder neste trabalho. Muitos autores, especialmente os acima já citados, defendem uma verdade material, com o objetivo de fazer justiça, consideram válida a relativização da coisa julgada, a despeito de tal cogitação ser refutada pelo próprio sistema do direito positivo.

Neste trabalho tomam-se como marcos teóricos as obras de Hans Kelsen, Lourival Vilanova, Paulo de Barros Carvalho, Tárek Moysés Moussallem, Fabiana Del Padre Tomé e Eurico Diniz de Santi e José Carlos Barbosa Moreira para o enfrentamento da problemática proposta.

O Direito como objeto cultural faz ser a si mesmo; fala dele mesmo e é senhor de seu tempo ${ }^{9}$. O direito é artificial ${ }^{10}$; cria suas próprias realidades. Tanto isso é verdade

\footnotetext{
7 XXXVI - A lei não prejudicará o direito adquirido, o ato jurídico perfeito e a coisa julgada;

8 DElgADO, José Augusto. Efeitos da Coisa Julgada e os Princípios Constitucionais, in Coisa Julgada Inconstitucional, Coord. Carlos Valder do Nascimento, Rio de Janeiro, América Jurídica, 2003, 3 ed: "Consoante se observa da leitura do dispositivo, a regra nele insculpida se dirige ao legislador ordinário. Trata-se, pois, de sobre-direito, na medida em que disciplina a própria edição de outras regras jurídicas pelo legislador, ou seja, ao legislar é interdito ao Poder Legiferante ‘prejudicará coisa julgada”.

9 A expressão o "Direito é senhor de seu tempo" é de CARVALHO, Paulo de Barros. Segurança Jurídica

e Modulação dos Efeitos, in Revista de Direito Tributário n. 102, pg. 23. Isso não significa que seja possível ao direito que normas jurídicas retroajam e maculem situações já consolidadas pelo tempo. Por isso o mestre Paulo de Barros Carvalho, no mesmo escrito, às fls. 26 consignou: "Nosso ordenamento positivo rejeita com força e veemência que as normas jurídicas retroajam para atingir situações consolidadas no tempo."

10 Nesse sentido DE SANTI, Eurico Marcos Diniz e CONRADO, Paulo Cesar. Controle Direto de Constitucionalidade e Repetição do Indébito Tributário, in Revista Dialética de Direito Tributário, n. 86: "Nada mais natural, o direito é artificial: inicia seu processo de positivação por intervenção formal das partes, conforme previsão da lei (lançamento, petição inicial etc.) e termina quando a lei definir, no caso do processo judicial, com a coisa julgada".
}

Revista de Teorias do Direito e Realismo Jurídico | e-ISSN: 2525-9601 | Minas Gerais | v. 1 | n. 2 | p. 208 - 241| Jul/Dez. 2015. 
que o Direito pode suspender um prazo; fazê-lo retroagir; constituir a prescrição ou a decadência de determinada cobrança; pode inclusive dizer que o navio (que social e aparentemente se move) é bem imóvel. Eis o direito criando suas próprias realidades ${ }^{11}$ !

A afirmação seguida de exemplificação feita pelo professor Tárek Moysés Moussallem ${ }^{12}$ deixa claro que isso:

\footnotetext{
“[...] explica por que o direito positivo cria suas próprias realidades. A significação atribuída a um "bem móvel" pelo direito não é a mesma atribuída pela comunidade. Da mesma forma, o sentido atribuído ao "casamento" é diferente na religião e no direito".
}

Por isso pode o direito reconhecer mecanismos legais (desde que não agridam o soberano princípio da segurança jurídica e os postulados constitucionais, por óbvio) para "relativizar sua coisa julgada", é o caso, como muito bem fez consignar o mestre processualista Barbosa Moreira: a ação rescisória e a revisão criminal. Por outro lado, utiliza-se a expressão "relativizar" aqui nesse exemplo como forma legal estipulada pelo Direito Positivo e apta a desconstituir a coisa julgada.

Tem-se como certo que, ainda sob esse contexto, o fim do direito é normatizar as ações humanas de determinada sociedade, regulamentando as condutas e pinçando os fatos que considera lícitos e os fatos que considera ilícitos. Faz isso por meio de seus antecedentes normativos que selecionam, ou recortam para usar terminologia ponteana, fatos sociais e soergue-os a eventos jurídicos. Levada a juízo a lide, em virtude de determinada discordância no âmbito do direito material, o juiz terá em suas mãos o instrumental franqueado pelo direito positivo para compor o litígio. Designará audiência para produção de provas; designará perícia; ouvirá a parte contrária, adjudicará o direito de recorrer etc. Será dado prosseguimento ao processo; ao influxo de positivação do direito.

\footnotetext{
${ }^{12}$ MOUSSALlEM, Tárek Moysés. Revogação em Matéria Tributária, São Paulo, 2004, p. 54.
} 
Partindo de normas gerais e abstratas o interprete analisará os fatos e constituirá a norma jurídica individual e concreta, outorgando a determinado fato jurídico um dever-ser (obrigação, proibição ou permissão) que ensejará relação jurídica entre um sujeito passivo e um sujeito ativo. Esse com direito subjetivo de "receber" o objeto que lhe compete e aquele o dever jurídico de cumprir com a determinação.

A "justiça" processual ${ }^{13}$, portanto, nesse curso, foi observada e o que o vencido na demanda quer é o que lhe é de direito reconhecido por sentença ${ }^{14}$. Em momento tal, passadas todas as etapas da positivação do direito, a coisa julgada é fundamental para pôr termo final àquele influxo (positivação do direito). É o momento em que as partes litigantes terão conhecimento de que todos os "efeitos práticos, sua situação, sub specie iuris, é aquela definida na sentença, e não outra qualquer"15.

O objetivo aqui proposto é de analisar a proposta da relativização da coisa julgada tida por inconstitucional sob a perspectiva intrassistêmica do direito positivo processual civil.

Para tanto, utilizou-se como metodologia, ou seja, o caminho percorrido para estudar o objeto de estudos, a análise pelo prisma da lógica formal, de modo a evitar contradições internas ao discurso científico. Somente o prisma normativo foi levado em consideração; este foi o corte metodológico: analisar a coisa julgada e sua (im) possível relativização de acordo somente com o sistema do direito positivo, abstraindo-se conceitos de outras ciências.

\footnotetext{
13 Por certo não se consideram aqui vícios legalmente previstos taxativamente no artigo 485 do CPC e que maculam afrontosamente a jurisdição, vide: Art. 485. A sentença de mérito, transitada em julgado, pode ser rescindida quando: I - se verificar que foi dada por prevaricação, concussão ou corrupção do juiz; II - proferida por juiz impedido ou absolutamente incompetente; III - resultar de dolo da parte vencedora em detrimento da parte vencida, ou de colusão entre as partes, a fim de fraudar a lei; IV - ofender a coisa julgada; V - violar literal disposição de lei;Vl - se fundar em prova, cuja falsidade tenha sido apurada em processo criminal ou seja provada na própria ação rescisória; Vll - depois da sentença, o autor obtiver documento novo, cuja existência ignorava, ou de que não pôde fazer uso, capaz, por si só, de Ihe assegurar pronunciamento favorável; VIII - houver fundamento para invalidar confissão, desistência ou transação, em que se baseou a sentença; IX - fundada em erro de fato, resultante de atos ou de documentos da causa;

14 Utiliza-se a palavra sentença aqui em sentido lato podendo significar também acórdãos dos Tribunais de 2 e 3 instâncias. 15 ob. cit. p. 245.
} 
No primeiro capítulo deste trabalho, serão apresentadas bases teóricas acerca no Direito, situando-o como objeto cultural possuidor de linguagem própria e constituidor de sua própria realidade, formador de um sistema autopoiético que controla sua criação e define a realidade intra-normativa.

Já no segundo capítulo, abordou-se o princípio da segurança jurídica. Demonstrouse que a análise do direito pelo prisma normativo pode levar à conclusão de que observância do direito positivo como um todo durante o processo de positivação, questionando sua racionalidade; respeitando seus prazos; analisando sua hierarquia interna; a coordenação e a subordinação ${ }^{16}$ entre suas normas jurídicas, o respeito às decisões são suficientes para notar a presença do princípio da segurança jurídica. Todo o sistema jurídico, portanto, está submetido a este princípio.

No terceiro e último capítulo, analisou-se especificamente a proposta de relativização da coisa julgada, especialmente analisada sob o prisma do novo Código de Processo Civil.

Espera-se que este trabalho contribua para um estudo do direito metodologicamente puro e normativo, separado rigorosamente de outras ciências, sem, é claro, deixar de reconhecer a importância dessas ciências.

\section{Algumas Considerações Importantes Acerca da Teoria Geral do Direito}

Partir do estudo da teoria do direito para analisar as categorias de qualquer ramo jurídico é premissa básica a ser adotada por todo jurista. A teoria do direito é geral e uniforme a todos os ramos didáticos do direito; antes de o direito ser administrativo, penal, processual civil ou mesmo civil ele é direito e, por esta razão, saber sua teoria permitirá ao cientista que sobre o direito se debruça instrumental poderoso e primordial para a compreensão do fenômeno do direito.

\footnotetext{
${ }^{16}$ CARVAlHO, Paulo de Barros. Segurança Jurídica e Modulação dos Efeitos, in Revista de Direito Tributário, n. 102, p. 21.
} 


\subsection{O Direito como Objeto Cultural}

Em virtude de seu caráter prescritivo de conduta, criando abstratamente os dados jurídicos como, por exemplo, o fato jurídico, sentença, recurso, coisa julgada e a relação jurídica o direito é criação da vontade humana. ${ }^{17}$ É criado pela vontade do homem. Não por outro motivo é que ao se adjudicar sentido e valor a uma determinada conduta tida por relevante, o sujeito culmina por criar o direito. Este, por ser oriundo de arbitramento de sentido e valor, é um dado cultural, possuindo, portanto, todas as características dos objetos culturais. As normas, por intermédio de seus antecedentes, selecionam arbitrariamente os fatos e as condutas sociais e as elevam ao plano do jurídico com o intuito de estabelecer uma relação imputacional atribuindo "direção aos fatos sociais"18.

17 CARVAlHO, Paulo de Barros. O Princípio da Segurança Jurídica em Matéria Tributária, in Revista de Direito Tributário n. 61.

18 A expressão em aspas é de CARVALHO, Paulo de Barros. Op. Cit. p. 75. 
Isso permite afirmar-se que o direito é constituído pela linguagem e, como tal é um fato institucional. Por isso afirmar José Juan Moreso ${ }^{19}$, com “[... toda seguridad, la afirmación de que el Derecho es dependiente del lenguaje es suceptible de suscitar un amplio acuerdo." Não obstante ser constituído por linguagem e, portanto, apresentar-se em linguagem, o direito positivo não é linguagem ${ }^{20}$. Se o fosse, seria objeto apenas da semiótica. Porém, ao cientista do direito tal análise não interessaria. Mas, a partir da análise da linguagem, tendo-a como índice temático, fornece ferramenta importante para o cientista que do Direito se ocupa.

Para Tárek Moysés Moussallem²1 “ “[...] a linguagem é componente inalienável de seu [direito] ser". Por isso, Paulo de Barros Carvalho ${ }^{22}$, com muita propriedade e arrimado nas lições de Hans Kelsen, leciona que: “[...] onde houver direito, haverá normas jurídicas (Kelsen). A que poderíamos acrescentar: e onde houver normas jurídicas haverá, certamente, uma linguagem em que tais normas se manifestem".

Por essa perspectiva, claro fica que o jogo da linguagem do direito, por ser um fato institucional, cria suas próprias realidades a ponto de não se pode falar em coincidência entre o mundo social e o mundo real. São dois mundos absolutamente distintos.

Lourival Vilanova ${ }^{23}$ esclarece essa peculiaridade, na medida em que o fato jurídico “[...] é o que ficou retido ou separado (abstraído) do suporte fático total: podem ou não coincidirem". Nesse contexto, é pertinente a doutrina de Gregório Robles ${ }^{24}$ :

O homicídio não existe na realidade natural, mas apenas na realidade normativa (direito, moral, religião etc.). Sempre existirá na realidade o matar, mas matar não é o mesmo que cometer homicídio. Para cometer homicídio é necessário cumprir os requisitos exigidos pela norma: capacidade, ação com determinadas características etc.

\footnotetext{
19 MORESO, José Juan. Lenguaje jurídico. In: El derecho y la justicia. 2. ed. Madrid: Trotta, 2000. p. 105 .

20 MOUSSALLEM, Tárek Moysés. Revogação em matéria tributária. São Paulo: Noeses, 2005 , p. 56.

21 Op. cit. op. 57.

22 CARVAlHO, Paulo de Barros, Direito Tributário: fundamentos jurídicos da incidência tributária. 2 ed. rev. São Paulo: Saraiva, 1999. p. 17.

23 VILANOVA, Lourival. Analítica do dever-ser. In: Escritos jurídicos e filosóficos. São Paulo: Axis Mundi, 2003. v. 2. p. 69.

24 ROBLES, Gregório. O direito como texto: quatro estudos de teoria comunicacional do direito. Trad. Roberto Barbosa Alves. Barueri: Manole, 2005.
} 
O fato social não albergado pela linguagem do direito não será relevante para o direito positivo, tampouco existirá para ele. Tárek Moussallem ${ }^{25}$ demonstra a linguagem do direito constituindo sua própria realidade interna, na medida em que, mesmo não havendo a morte física (fato bruto morte), pode, para o direito, haver a morte jurídica, como a ausência, por exemplo.

A morte natural, ainda segundo a exemplificação do professor capixaba, pode assumir muitos sentidos no interior do sistema do Direito Positivo, como: "homicídio", "sucessão", "sinistro" etc. A propósito, vale consigna o ensinamento de Wilbur Marshall Urban ${ }^{26}$ :

\footnotetext{
Sólo cuando la cultura se actualiza en el lenguaje y en otras formas relacionadas con el lenguaje, la vida sale de la existência puramente "natural"y dada; sólo entonces es cuando pasa de los procesos meramente biológicos a las formas de inteligencia y espíritu.
}

Nesse sentido, somente haverá direito onde houver linguagem. O cientista do direito não vai ao direito senão por intermédio da linguagem que o permita. Todavia, não se há confundir a linguagem do direito positivo com a linguagem da ciência que o descreve. Aquela é irredutível a esta; o ser é irredutível ao dever-ser ${ }^{27}$.

A ciência do direito possui função descritiva de seu objeto (Direito Positivo). O Direito Positivo, por outro lado, tem função de prescrever condutas. Aquela é metalinguagem sobre essa última e a linguagem da ciência do direito não é apta a mudar a linguagem do Direito Positivo ${ }^{28}$.

\footnotetext{
${ }^{25}$ Op. cit. p. 58.

${ }^{26}$ URBAN. Wilbur Marshall. Lenguaje y realidad: la filosofía del lenguaje y los principios del simbolismo. Trad. Carlos Villegas y Jorge Portilla. México/Buenos Aires: 1952. p. 311.

${ }^{27}$ CARVAlHO, Paulo de Barros. Curso de Direito Tributário. 25 ed. São Paulo: Saraiva, 2013. p. 31.

${ }^{28}$ CARVALHO, Paulo de Barros. Curso de Direito Tributário. 25 ed. São Paulo: Saraiva, 2013. p. 32 33.
} 
Por isso afirmar Lourival Vilanova ${ }^{29}$ que não ocorre a quebra do "[...] sistema normativo o fato de que enunciados científicos nele ingressem, convertendo-se em normas. Porém, é necessário que norma do sistema, explícita ou implícita, o faça, indicando o órgão e/ou o procedimento [...].”

Assim, tanto o Direito Positivo como a ciência que o descreve compõem-se de linguagem e sem ela como componente necessário e fundamental, não haverá nenhum desses dois planos linguísticos (prescritivo e descritivo).

Essa circunstância não passou ao largo de Alessandra Gondim Pinho ${ }^{30}$ quando brilhantemente afirma:

\begin{abstract}
"Num ou noutro campo, enfim, a linguagem é o instrumento que nos leva ao nível do saber, do conhecimento. Sem linguagem não há direito, nem como sistema de normas que orientam condutas, tampouco como conjunto de enunciados que o interpretam".
\end{abstract}

O ser composto de linguagem significa que o Direito Positivo é resultado de intervenção do homem que, imbuído de seus valores culturais, cria-o ${ }^{31}$. Eis, portanto, o Direito surgindo como objeto cultural. Recaséns Siches $^{32}$ fornece conceito de objeto cultural:

\footnotetext{
29 VILANOVA, Lourival. Níveis de linguagem em kelsen. In: Escritos jurídicos e filosóficos. São Paulo: Axis Mundi, 2003. v. 2. p. 205.

30 PINHO, Alessandra Gondim. Fato jurídico tributário. São Paulo: Noeses, 2001. p. 40/41.

31 Vale aqui consignar os ensinamentos de VILANOVA, Lourival. Sobre o conceito de direito. In: Escritos jurídicos e filosóficos. São Paulo: Axis Mundi, 2003. v. 1. p. 40, "o direito não é algo simples. Nele se entrecruzam o psíquico, o socialhistórico, os valores. Em síntese, o direito é objeto cultural. Parte componente da cultura, regido por uma dialética própria, ao mesmo tempo pela dialética que afeta a cultura em seu conjunto, e, assim, sujeito a relações mútuas com os demais aspectos da cultura, como aeconomia, a religião, a ciência etc."

32 SICHES, Luis Recásens. Tratado de Sociologia, vol. I. trad. João Baptista Coelho Aguiar, Porto Alegre, Globo, 1970, p. 194/195. Também este autor, em obra jurídica, ensina que o Direito é um objeto cultural, nas palavras do autor SICHES, Luis Recásens, Introducción al estudio del derecho. México: Porruá, 2006. p. 27: "Llamamos cultura todo aquello que los miembros de una determinada sociedad concreta aprenden de sus predecesores y contemporâneos em esa sociedad, y lo añaden a ese legado y las modificaciones que operan en el mismo. Em tal sentido, cultura es la herencia social utilizada, revivida y en parte - mayor o menor - modificada. Pues bien, el Derecho, las normas jurídicas, en tanto que son vividas actualmente, re-vividas, en tanto que son cumplidas por sus sujetos y, en tanto que, llegado el caso, son individializadas por los órganos jurisdiccionales quienes importen inexorablemente su ejecución, constituye una parte de la cultura de un pueblo; pertenecen al reino de lo que podríamos llamar cultura viva."
} 
Existe no mundo uma serie de objetos e coisas que não são feitos nem produzidos pela natureza, mas são criados pelo homem ou resultam da atividade dêles (sic). (...) seu ser essencial, aquilo que propriamente são, não se constitui por êsses componentes [materiais], mas por seu sentido ou significação, por serem a expressão da intencionalidade humana. (...) $\mathrm{O}$ conjunto dêsses objetos é comumente denominado "mundo da cultura".

É o Direito como resultado da intervenção do homem, dependente da linguagem para sua existência, a criar sua própria realidade em seu interior. Sendo assim, somente após sofrer a intervenção da escolha do fato social é que se poderá chamar o fato de jurídico e relevante ao direito. É a linguagem perpassando e criando a realidade. Essa perspectiva levou o jurista Hans Kelsen à distinção entre o mundo do ser (mundo natural) e o mundo do dever-ser (mundo cultural criado pelo homem), vide as palavras do doutrinador austríaco ${ }^{33}$ :

Proposições ou leis jurídicas em que são representadas as normas positivas estabelecidas por um legislador ou através do costume são, por exemplo, as seguintes: quando alguém comete um crime, deve ser punido; quando alguém não paga o que deve, deve ser executado o seu patrimônio. A distinção entre a causalidade e a imputação reside em que a relação entre o pressuposto, como causa, e a conseqüência, como efeito, que é expressa na lei natural, não é produzida, tal como a relação entre pressuposto e conseqüência que se estabelece numa lei moral ou jurídica, através de uma norma posta pelos homens, mas é independente de toda a intervenção desta espécie.

${ }^{33}$ KELSEN, Hans. Teoria Pura do Direito. São Paulo: Martins Fontes, 2000, p. 200-201. 
Quando se afirma que o direito é artificial, toma-se por base a constatação de que é um objeto cultural arraigado de postulados axiológicos voltados à regulamentar a ação humana nas mais diversificadas situações sociais. Daí se nota a impossibilidade de aproximar-se desse conjunto despojando-se dos valores inerentes34 de determinado núcleo social. Ao recortar os fatos que entende relevantes juridicamente, o direito valoradeterminada atitude lícita e determinada atitude ilícita. Isso ocorre por meio dos atos defala. Com a coisa julgada não foi diferente; o direito positivo criou dispositivo legal que impôs fim às expectativas de uma determinada lide. Não se deve olvidar, ainda, para a expressa prescrição em nível constitucional da coisa julgada plasmada no inciso XXXVI do art. 5, no sentido de que “[...] a lei não prejudicará o direito adquirido, o ato jurídico perfeito e a coisa julgada". Por intermédio da coisa julgada, o dever-ser normativo ganha foros de imutabilidade, permitindo que as partes saibam suas obrigações na medida da decisão. Permite-se, assim, a segurança das partes de que aquela situação passada em julgado será sempre respeitada a partir daquele átimo nas vindouras interações humanas. Com a coisa julgada, o deverser reforça seu poder-ser permitindo aos acobertados pela autoridade daquele instituto jurídico de cumprir a ação prevista35 ou mesmo de omití-la (conforme restar plasmado da decisão transitada em julgado). Paulo de Barros Carvalho36, lecionando sobre tema semelhante, assevera que:

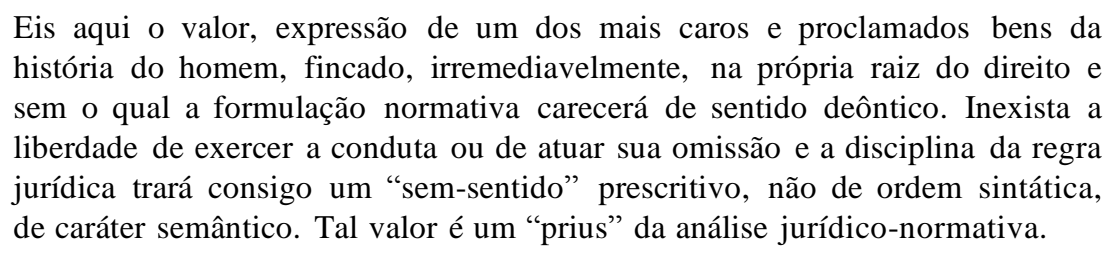

Essa premissa é fundamental e necessária para a análise da coisa julgada, pois ela (coisa julgada) é um instituto jurídico que tem por função pôr fim à positivação do direito. Assim, encampar o dever-ser normativo, sua desconstituição somente pode se dar em hipóteses excepcionalíssimas, previstas apenas e tão-somente pelo direito positivo, e jamais permitir que a expectativa deôntica salvaguardada pela coisa julgada perca seu sentido de pacificar condutas e estipular a justiça formal entre as partes.

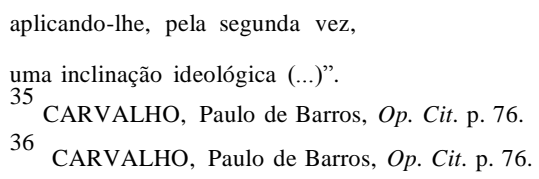




\title{
1.2. O Direito Como Sistema Autopoiético: a ideia de Gunter Teubner
}

A postura de tomar-se o direito positivo como objeto cultural permite a sua análise como um sistema autopoiético que, segundo as palavras de Gunter Teubner ${ }^{37}$ :

\begin{abstract}
"O sistema jurídico dos nossos dias pode ser visto como um sistema autopoiético de segundo grau. Trata-se de um sistema constituído por actos de comunicação particulares gravitando em torno da distinção "legal/ilegal", que se reproduzem como actos jurídicos a partir dos actos jurídicos”.
\end{abstract}

Para Teubner, o subsistema do direito positivo é autônomo perante os outros subsistemas sociais, de modo que as diretrizes de outros subsistemas, tais como a moral, a economia, a religião, em que pesem conviverem harmonicamente com o subsistema do direito, somente ingressam nesse último se ele o permitir. Isso nada mais significa que o direito regula sua própria criação e se comunica por si próprio, é o que o autor alemão denomina de clausura comunicativa. É o sistema do direito positivo como criação do homem, portanto, como objeto cultural, sendo auto-referencial e auto- reprodutivo de seus próprios atos jurídicos. Assim, o sistema do direito positivo deve guiar-se pelas regras de seu sistema. Não se há confundir as regras endógenas da Moral ou da religião com as regras endógenas do direito. Trilhando essa exata senda, o professor Lourival Vilanova ${ }^{38}$ aduz que

A validade é, assim, validade no interior do sistema positivo. Normas de outra procedência, ou de outro conteúdo, para ingressarem no sistema, requerem regra-de-regra que as jurisdicize, que as com-valide. A correspondência com tais regras "processuais" dá-lhes relação-de-pertinência face ao sistema positivo.

\footnotetext{
37 TEUbner, Gunther. O Direito como Sistema Autopoiético, Lisboa, Fundação Calouste Gulbenkian,1993 p. 140.

38 VILANOVA, Lourival. Estruturas Lógicas e o Sistema do Direito Positivo, São Paulo: Noeses, 2005, p. 29.
}

Não, por outro motivo, o sistema do direito positivo não permitir regras a ele desconhecidos penetrem seu interior sem a prévia filtragem jurídica. É o que Gunther 
Teubner $^{39}$, portanto, denominou de autopoiese do sistema do direito positivo. Em outras palavras, o direito positivo somente trava contato com outros sistemas quando suas estruturas assim o permitirem, tomando-se isto como premissa fundamental para, em tópico próprio, analisar-se o cabimento de mecanismos para relativizar a coisa julgada tida por inconstitucional.

\subsection{Ainda algumas considerações sobre o Sistema do Direito Positivo}

Tárek Moysés Moussallem ${ }^{40}$ partindo das lições de Alchourrón e Bulygin atribui a expressão `sistema do direito positivo’ para se referir ao conjunto de normas estaticamente consideradas. Continua o doutrinador capixaba que:

\footnotetext{
"A voz `ordenamento jurídico' é usada no sentido dinâmico `de sequência de conjunto de normas' ou seja, ‘uma ordem jurídica é, de acordo com esta convenção, uma sequência de sistemas normativos”.
}

Partem esses autores, do sistema kelseniano de sistemas estáticos e sistema dinâmicos. De acordo com Moussallem, ${ }^{41}$ haveria um “ [...] sistema estático ao se empregar o critério de dedutibilidade às normas, tornando-o um sistema dedutivo, e seria sistema dinâmico quando se trabalhasse com o critério de legalidade".

\footnotetext{
39 TEUBNER, Op. Cit. p, 45.

40 MOUSSALLEM, Tárek Moysés. Revogação em Matéria Tributária, São Paulo: Noeses, 2005, p. 
E, continua o professor da Universidade Federal do Espírito Santo a afirmar que o ordenamento jurídico não é um conjunto de normas, mas sim, um sequencial temporal de normas. Dessa maneira, toda norma é válida somente se estiver relacionada a um sistema de direito positivo específico. A afirmação que N1 é válida carece de sentido, porquanto a validade de determinada norma somente se constata se relacionada a determinado sistema de direito positivo. Dessa forma, o correto é dizer "N1 é válida em SDP1".

Esse entendimento permitiu ao autor chegar à conclusão de que N1, produzida em SDP1, em determinado tempo (t1), mesmo que revogada posteriormente por $\mathrm{N} 2$, jamais deixará de pertencer ao SDP1. Por isso asseverou Moussallem ${ }^{42}$ que, “[...]: Uma vez, pertencente a um SDP determinado, a norma jurídica jamais deixará de lhe pertencer. Eis a atemporaridade da proposição normativa".

Por outras palavras: se determinada norma (N1) produzida em T1 é julgada inconstitucional sobrevindo, com isso, (N2) produzida em T2 não tem o condão de tirar a validade de N1, mas “impede (após a declaração da inconstitucionalidade) a aplicação da norma para os casos ocorridos sob seu intervalo de subsunção e para os casos ocorridos após a "declaração" de inconstitucionalidade",43

Ora, pretende-se, com isso, demonstrar, como noção propedêutica do que adiante será analisado, é que havendo a norma jurídica "coisa julgada” construída sobre a norma abstrata e geral N1 em T1, a posterior declaração de inconstitucionalidade da norma N1 (nos termos, por exemplo, do parágrafo 15 do artigo 525 do CPC/2015 não é instrumental apto a expulsar a norma coisa julgada, na exata medida em que, Moussallem, arrimado em Alchourrón e Bulygin, afirmou que jamais a norma N1 deixará de pertencer ao SDP1. Se sobre ela recaiu a coisa julgada, impossível será sua modificação fora das exceções estipuladas pelo direito positivo ${ }^{44}$.

42 MOUSSALLEM, Op. Cit. p. 133.

43 MOUSSALLEM, Op. Cit. p. 240.

44 Estamos com DE SANTI, Eurico Marcos Diniz e CONRADO, Paulo Cezar. Controle Direto de Constitucionalidade e Repetição do Indébito Tributário, in Revista Dialética de Direito Tributário, n.86, p. 31. quando doutrinam: "A alegação de 'violação a literal disposição de lei'(inciso V), também não é cabível, pois o acórdão proferido na ADInx, posterior à sentença no momento de sua produção. Aplica-se ao fato a lei vigente à época do seu acontecimento: é regra geral do direito. À época da produção da sentença, era vigente e válida a lei $(\mathrm{Lx})$ e convencido o juízo da ação de repetição do indébito sobre sua conformidade à Constituição, impossível, agora, acusá-lo de desrespeito à literalidade da lei: só se pode controlar atos no horizonte presente de sua produção, não em relação a pronunciamento decorrente de uma ação imprescritível e em tempo futuro e incerto, como a ADIn". 


\section{Especificamente o princípio da segurança jurídica: o respeito ao sistema do direito positivo}

Tomando o direito positivo como o conjunto de normas válidas em um determinado momento histórico e em determinado lugar, é possível notar que, ao lado das entidades normativas, lugar não há para outras quaisquer que não sejam normas jurídicas dotadas de mesmo esquema sintático de organização (se A então deve-ser B). Com isso, não é possível ainda sustentar-se a existência dos princípios ao lado de normas jurídicas. Em verdade, princípios nada mais são do que normas que exercem grande força axiológica dentro do ordenamento jurídico, fazendo com que essas normas de caráter axiológico proeminente influenciem "vigorosamente sobre a orientação de setores da ordem jurídica" ${ }^{\natural 5}$. Esse caráter axiológico é presente em todo objeto cultural; como o direito é objeto cultural, sua carga axiológica é componente fundamental em sua composição.

Tal carga axiológica (valores), porém, deve respeitar à sistemática do direito como sistema autopoiético possuidor de autonomia sistêmica e criador de suas próprias realidades, de modo que devem ser afastadas todas as cogitações relativas à criação de valores não presentes na sistemática jurídica. Crer em um direito autônomo e capaz de criar suas próprias realidades, não se permite crer haver um sistema suprapositivo de valores, ou mesmo valores que valem por si mesmos. Somente os valores reconhecidos pelo direito serão levados em consideração; não outros sobre-valores, ao estilo do direito natural ${ }^{46}$.

\footnotetext{
45 Carvalho, Paulo de Barros. O Princípio da Segurança Jurídica, in Revista de Direito Tributário,

n. 61, p. 78: "É o nome que se dá a regras do direito positivo que introduzem valores relevantes para o sistema, influindo vigorosamente sobre a orientação de setores da ordem jurídica.

46 Esse é o entendimento de CARVALHO, Paulo de Barros, Op. Cit. p.80.
} 
Os princípios nem sempre encontram-se expressos nos textos normativos; por vezes aparecem de maneira explicita como o princípio da legalidade que basta leitura do inciso II do artigo $5^{\circ}$ da Constituição da República Federativa do Brasil de 1988 para verificar a sua prescritividade. Há, todavia, princípios que o intérprete extrai da implicitude dos textos normativos. De acordo com Paulo de Barros Carvalho ${ }^{47}$, todos têm a mesma força vinculante perante o ordenamento jurídico.

Observando-se o ordenamento jurídico do seu nível mais alto até sua base, notase que a República Federativa do Brasil de 1988 está plasmada de princípios que almeja serem observados quando da aplicação das normas jurídicas. Sim, porque não faria sentido estipular-se uma diretriz axiológica, se esta encontrar-se apenas em plano sintático e em desconformidade com o âmbito pragmático, em que a linguagem jurídica desce até às situações fáticas e verificar se aquelas diretrizes estáticas estão sendo observadas pelos utentes da linguagem. Deve haver, assim, uma constante verificação da aplicação dos postulados positivados e que refletem valores no sistema jurídico.

Dessa forma, a observância do direito positivo como um todo durante o processo de positivação, questionando sua racionalidade; respeitando seus prazos; analisando sua hierarquia interna; a coordenação e a subordinação ${ }^{48}$ entre suas normas jurídicas, o respeito às decisões, são suficientes para notar a presença do princípio da segurança jurídica. É do respeito pelo direito positivo, portanto, que se extrai a diretriz principiológica da segurança jurídica.

\footnotetext{
47 CARVAlHO, Paulo de Barros. Segurança Jurídica e Modulação dos Efeitos, in Revista de Direito Tributário, n. 102, p. 20.

48 CARVALHO, Paulo de Barros. Segurança Jurídica e Modulação dos Efeitos, in Revista de Direito Tributário, n. 102, p. 21.
} 
Embora não explicitada nos textos, a segurança jurídica realiza-se quando se efetivam outros princípios que compõem o sistema, tais como a legalidade, universalidade de jurisdição, devido processo legal, igualdade etc. Não por outro motivo se afirma que é o respeito ao direito positivo. Perfeita a observação de Gustavo Valverde $^{49}$, arrimado em Tércio Sampaio Ferraz Jr.:

O conceito de segurança jurídica repousa no aspecto intuitivo de que onde o direito é claro e delimitado ele "cria condições de certeza e igualdade que habilitam o cidadão a sentir-se senhor de seus próprios atos e dos atos dos outros. E como acuradamente observa, a segurança jurídica exige positividade do direito: 'se não se pode fixar o que é justo, ao menos que se determine o que é jurídico'. Nesse sentido, 'segurança significa clara determinação e proteção do direito contra o não-direito'.’'

Essa assertiva deixa claro que o direito positivo, por ser autônomo e criador de suas próprias realidades (autopoiético) instituiu um momento para que seu percurso narrativo tivesse um fim: a coisa julgada. Após o esgotamento de todas as possibilidades disponíveis pelo direito para a composição da pendenga judicial, é preciso um fim. Ainda que tido por "injusto", “irrazoável” ou mesmo “desproporcional".

Pautados sob essa mesma premissa, Eurico Marcos Diniz de Santi e Paulo Cesar Conrado $^{50}$ lecionam:

\footnotetext{
"A coisa julgada não serve para fazer justiça material, serve para outorgar segurança ao direito, segurança às partes da contenda, segurança a terceiros que encontram na coisa julgada um porto seguro para realização de outros negócios jurídicos. Faz, a seu modo, outra justiça: a formal, a única que importa ao direito."
}

Firma-se mais esta premissa: a coisa julgada serve para pôr fim à positivação do direito e fazer justiça formal ${ }^{51}$.

\footnotetext{
${ }^{49}$ VALVERDE, Gustavo Sampaio. Coisa Julgada em Matéria Tributária, São Paulo, Quartier Latin,

2004, p. 120. Em página 123 continua: “A Coisa julgada tem um objetivo claro: implementar segurança jurídica no sistema, reforçando a sua redundância".

50

50 DE SANTI, Eurico Marcos Diniz e CONRADO, Paulo Cesar. Op. Cit, p. 30.

51 MOREIRA, Barbosa. Considerações Sobre a Chamada "Relativização" da Coisa Julgada Material, Op. Cit, tem interessante opinião sobre isso: "o que ele (ordenamento) faz, para evitar eternização de incertezas, é preexcluir, de certo momento em diante, e com as ressalvas expressas a seu ver aceitáveis, que se volta a cogitar do dilema "justo ou injusto"

no concernente ao teor da sentença. Se assim, num caso ou noutro, se leva à eternização de alguma injustiça, esse é o preço que o ordenamento entendeu razoável pagar como contrapartida da preservação de outros valores"
} 


\section{Sobre a Inconstitucionalidade da Coisa Julgada Inconstitucional! A} Equivocada “Criação" de Ação Rescisória Invertida

Toda modificação no ordenamento jurídico que não respeite sua autonomia cria ruído prejudicial à sistemática do direito positivo. Como já ressaltado, o sistema do direito positivo é autopoiético, e, por assim o ser, fala de si mesmo e é autônomo. Qualquer influxo externo a ele, somente por intermédio de seu filtro poderá penetrar.Esse pressuposto metodológico servirá de base para a análise da novel cogitação de relativizarse a coisa julgada tida por inconstitucional. Neste capítulo analisar-se-á o cabimento desta situação.

\subsection{Coisa Julgada Inconstitucional é uma Inconstitucionalidade!}

Salta aos olhos que, não existindo quaisquer dispositivos normativos albergados pelo direito positivo, impossível será defender-se sua permanência, sob o risco criar-se ruído nefasto (ilegalidade ou inconstitucionalidade) no sistema jurídico. A ofensiva à Constituição pela sentença/acórdão tem previsão expressa no artigo 102, n. III da Constituição da República Federativa do Brasil de 1988 para sanar essa mácula: é o recurso extraordinário. Na hipótese de haver transitado em julgado a decisão/acórdão caberá Ação Rescisória ${ }^{52}$.

Não é demais repetir que tais remédios não se correlacionam por força da injustiça da sentença ${ }^{53}$. Algumas vezes, a sentença proferida à revelia do réu pode ter sido “justa”. Houve, somente, vício processual que o sistema do direito positivo entendeu por relevante e decidiu por extirpá-lo por intermédio daquele expediente jurídico.

\footnotetext{
52 É pacífico na doutrina que as hipóteses enumeradas nos incisos do artigo 485 do Código de Processo Civil são taxativas, nesse sentido Barbosa Moreira, Comentários ao Código de Processo Civil., volume V, Rio de Janeiro, Forense. 2005, p. 154.

53 MOREIRA, Barbosa. Op. Cit. p. 258.
}

Revista de Teorias do Direito e Realismo Jurídico | e-ISSN: 2525-9601 | Minas Gerais | v. 1 | n. 2 | p. 208 - 241| Jul/Dez. 2015. 
Eis as hipóteses de "relativização" da coisa julgada no ordenamento jurídico brasileiro. Visar ao combate da coisa julgada fora das exatas fronteiras criadas pelo direito trará prejuízos à segurança jurídica dos jurisdicionados, situação essa que se configurará plenamente inconstitucional, por violação frontal ao inciso XXXVI do artigo $5^{\circ}$ da República Federativa do Brasil de 1988 Aliás, reconhecendo os limites impostos pelo direito positivo, o Supremo Tribunal Federal já decidiu ${ }^{54}$, vide:

\footnotetext{
${ }^{54}$ Não se perca de vista que o Superior Tribunal de Justiça também tem julgado com o mesmo entendimento, vide : AÇÃO DE NEGATIVA DE PATERNIDADE. EXAME PELO DNA POSTERIOR AO PROCESSO DE INVESTIGAÇÃO DE PATERNIDADE. COISA JULGADA.

1. SERIA TERRIFICANTE PARA O EXERCICIO DA JURISDIÇÃO QUE FOSSE ABANDONADA A REGRA ABSOLUTA DA COISA JULGADA QUE CONFERE AO PROCESSO JUDICIAL FORÇA PARA GARANTIR A CONVIVENCIA SOCIAL, DIRIMINDO OS CONFLITOS EXISTENTES. SE, FORA DOS CASOS NOS QUAIS A PROPRIA LEI RETIRA A FORÇA DA COISA JULGADA, PUDESSE O MAGISTRADO ABRIR AS COMPORTAS DOS FEITOS JA JULGADOS PARA REVER AS DECISÕES NÃO HAVERIA COMO VENCER O CAOS SOCIAL QUE SE INSTALARIA.EMENTA: CONSTITUCIONAL. PROCESSUAL. MANDADO DE SEGURANÇA PREVENTIVO. SERVIDOR PÚBLICO: VANTAGEM DEFERIDA POR SENTENÇA JUDICIAL TRANSITADA EM JULGADO. TRIBUNAL DE CONTAS: DETERMINAÇÃO NO SENTIDO DA EXCLUSÃO DA VANTAGEM. COISA JULGADA: OFENSA. CF, art. $5^{\circ}$, XXXVI. I. - A segurança preventiva pressupõe existência de efetiva ameaça a direito, ameaça que decorre de atos concretos da autoridade pública. Inocorrência, no caso, desse pressuposto da segurança preventiva. II. - Vantagem pecuniária, incorporada aos proventos de aposentadoria de servidor público, por força de decisão judicial transitada em julgado: não pode o Tribunal de Contas, em caso assim, determinar a supressão de tal vantagem, por isso que a situação jurídica coberta pela coisa julgada somente pode ser modificada pela via da ação rescisória. III. - Precedentes do Supremo Tribunal Federal. IV. - Mandado de Segurança preventivo não conhecido. Mandado de Segurança conhecido e deferido relativamente ao servidor atingido pela decisão do TCU. (MS 25009, Relator(a): Min. CARLOS VELLOSO, Tribunal Pleno, julgado em 24/11/2004, DJ 29-04-
}

2005 PP-00008 EMENT VOL-02189-02 PP-00229 LEXSTF v. 27, n. 319, 2005, p. 135-150 RTJ VOL-00194-02 PP-00594)

A REGRA DO ART. 468 DO CODIGO DE PROCESSO CIVIL E LIBERTADORA. ELA ASSEGURA QUE O EXERCICIO DA JURISDIÇÃO COMPLETA-SE COM O ULTIMO JULGADO, QUE SE TORNA INATINGIVEL, INSUSCETIVEL DE MODIFICAÇÃO. E A SABEDORIA DO CODIGO E REVELADA PELAS AMPLAS POSSIBILIDADES RECURSAIS E, ATE MESMO, PELA ABERTURA DA VIA RESCISORIA NAQUELES CASOS PRECISOS QUE ESTÃO ELENCADOS NO ART. 485. 2. ASSIM, A EXISTENCIA DE UM EXAME PELO DNA POSTERIOR AO FEITO JA JULGADO, COM DECISÃO TRANSITADA EM JULGADO, RECONHECENDO A PATERNIDADE, NÃO TEM O CONDÃO DE REABRIR A QUESTÃO COM UMA DECLARATORIA PARA NEGAR A PATERNIDADE, SENDO CERTO QUE O JULGADO ESTA COBERTO PELA CERTEZA JURIDICA CONFERIDA PELA COISA JULGADA.

3. RECURSO ESPECIAL CONHECIDO E PROVIDO. 
(REsp 107248/GO, Rel. Ministro CARLOS ALBERTO MENEZES DIREITO, TERCEIRA TURMA, julgado em 07/05/1998, DJ 29/06/1998 p. 160)

Todavia, vem ganhando espaço na doutrina atual proposta de sobrepujarem-se os limites já previstos no ordenamento jurídico e "relativizar" a coisa julgada maculada de injustiça, irrazoabilidade, desproporcionalidade, imoral e ilegal ${ }^{55}$. Humberto Theodoro Júnior e Juliana Cordeiro de Faria ${ }^{56}$ chegam a afirmar ainda que "[...] a segurança como valor inerente à coisa julgada e, por conseguinte, o princípio de sua intangibilidade são dotados de relatividade, mesmo porque absoluto é apenas o DIREITO JUSTO.”

Afora esses casos, outros dois foram paradigmáticos para a idéia da relativização da coisa julgada tida por inconstitucional: os exames de DNA que provariam a paternidade ou mesmo a negariam após o trânsito em julgado da sentença e a desapropriação de um terreno em São Paulo, o qual teria sido pago em valor irreal ${ }^{57}$ (mais do que o justo valor).

\footnotetext{
55 DELGADO, José Augusto. Efeitos da Coisa Julgada e Princípios Constitucionais, in Coisa Julgada Inconstitucional, volume coletivo organizado por Carlos Valder do Nascimento, Rio de Janeiro (3 ed., 2004), p. 54. Também com a mesma ideia: DINAMARCO, Cândido Rangel: Relativizar a Coisa Julgada

Material, in Revista de Processo, n. 109, p. 22.

56 THEODORO JUNIOR, Humberto e CORDEIRO DE FARIA, Juliana. A Coisa Julgada Inconstitucional e os Instrumentos para seu Controle, in Coisa Julgada Inconstitucional, volume coletivo organizado por Carlos Valder do Nascimento, Rio de Janeiro (3 ed., 2004), p. 93.

57 GÓES, Gisele Santos Fernandes. A Relativização da Coisa Julgada: Exame Crítico (Exposição de um Ponto de Vista Contrário), in Relativização da Coisa Julgada, volume coletivo organizado por Fredie Didier Jr., Salvador (2. ed., 2 tiragem 2008), p. 172. "O da desapropriação com um valor de indenização totalmente irreal (mais do que o justo valor) suscitou para os relativistas a tomada de posição de desconsideração da coisa julgada, porque a decisão transitada em julgado ofendia nitidamente o princípio da moralidade administrativa."
} 
Aqui é o exato momento em que todos os pressupostos epistemológicos anteriormente traçados deságuam e oferecem instrumental para solucionar essas supostas hipóteses excepcionais. Com efeito, por ser objeto fruto da criação humana e por ser um sistema autopoiético, o direito escolheu o momento em que sua narrativa teria fim: a coisa julgada. Decidiu também as hipótese excepcional para combater a coisa julgada: ação rescisória (art. 966 do CPC/2015).

O fato de uma das partes considerar a decisão transitada em julgado injusta, irrazoável ou mesmo desproporcional não tem o condão de desconstituir a coisa julgada já formada. Por isso Nelson Nery Junior ${ }^{58}$ afirmar:

\begin{abstract}
“Entre o justo absoluto, utópico, e o justo possível, realizável, o sistema constitucional brasileiro, a exemplo do que ocorre na maioria dos sistemas democráticos ocidentais, optou pela segunda (justo possível), que é consubstanciado na segurança jurídica da coisa julgada material. Descumprirse a coisa julgada é negar o próprio Estado democrático de direito, fundamento da república brasileira.”
\end{abstract}

A justiça, a razoabilidade, a moralidade ou mesmo a proporcionalidade devem ter um fim. E o direito positivo atento a esta particularidade criou a coisa julgada. É por meio dele que se criam as ações por ele permitidas, proibidas ou obrigatórias. É o que Gregório Robles ${ }^{59}$ ensina:

\begin{abstract}
"O texto jurídico é um texto prescritivo. O que significa isto? Significa, sobretudo, que o texto está dotado, como uma totalidade, de uma função pragmática determinada que o converte num conjunto de mensagens cujo sentido intrínseco é dirigir, orientar ou regular as ações humanas. Além disso, o próprio texto cria as ações que podem ser qualificadas como jurídicas, e o fato de regular a ação não significa que a ação jurídica exista antes do texto, mas sim que é o texto que a constitui. Por estranho que possa parecer, o homicídio como ação jurídica só existe depois que texto jurídico prescreve o que é que se deve entender por homicídio.”
\end{abstract}

\footnotetext{
58 JUNIOR, Nelson Nery. Coisa Julgada e Estado Democrático de Direito, in Revista Forense, vol. 375, p. 145. Às fls. 157 continua: "O juízo de valor da justiça da sentença feito posteriormente, para que se tenha como acobertada ou não pela coisa julgada material, por ser instrumento e mecanismo do totalitarismo, violenta frontalmente o Estado democrático de direito (CF, art. 1, caput) e, portanto, não tem substrato de sustentação no sistema constitucional brasileiro. O magistrado da segunda ação, posterior (que pode até ser um juiz substituto, recém-ingressado na carreira), seria o juiz da justiça ou da injustiça da sentença anterior, que pode até ter sido prolatada pelo STF! Maior Arbítrio do que esse? Impossível."

59 ROBLES, Gregório. O Direito como Texto: Quatro Estudos de Teoria Comunicacional do Direito, trad. Roberto Barbosa Alves, Barueri, Manole, 2005, p. 29.
} 
Afasta-se, assim, a possibilidade de "relativizar" a coisa julgada nesses últimos casos. Agora, a pergunta é: no caso de exame de DNA que prove a paternidade ou a não paternidade de alguém, ainda que já transitada em julgado a sentença, é possível a "relativização" da coisa julgada?

Também nessa situação cogitada, por mais apelativa e comovente que seja socialmente (mundo do ser), não se deve "relativizar" a coisa julgada (mundo do deverser). Também aqui nossas premissas retornarão para responder a pergunta formulada. $\mathrm{O}$ direito, por ser um objeto cultural criado pelo homem e possuir suas próprias estruturas internas autônomas, prevê as formas probatórias que entende corretas para provar determinado fato.

Pondera-se que o fato social, mesmo que evidenciado em plano social como "verdade", nem sempre entra dessa forma no mundo do direito. Corrobora esse entendimento o ensinamento de Paulo de Barros Carvalho ${ }^{60}$ :

"É certo que, por vezes, o direito admite a utilização da linguagem natural, para atestar a realização de eventos ocorridos no setor sobre o qual legisla. Todavia, é enorme a gama de situações da vida social, em que a ordem jurídica exige uma linguagem específica, prescrevendo documentos e estabelecendo condutas que, marcadamente, refogem do trato ordinário que as pessoas mantêm na comunicação usual. É exatamente nesse intervalo que se verifica discrepância entre o mero acontecimento social e o fato jurídico, propriamente dito. Fala-se, por isso, numa verdade material que nem sempre se identifica com a verdade jurídica".

${ }^{60}$ CARVAlHO, Paulo de Barros. A Prova no Procedimento Administrativo Tributário, in Revista Dialética de Direito Tributário, n. 34.p, 106. 
A essa altura já se permite afirmar que a "paternidade social” não é a mesma "paternidade jurídica". Se, em determinado tempo (T1) após procedimento legal observado foi enunciada norma jurídica individual e concreta (N1) que reconheceu a paternidade de um indivíduo pelas provas que à época eram disponíveis e, essa norma transitou em julgado, essa é a verdade para o direito. Ou seja: o "pai jurídico" é esse indivíduo especificado nessa norma individual e concreta. Isso é conseqüência de o direito ser um objeto cultural e um sistema autopoiético.

Gisele Santos Fernandes Góes ${ }^{61}$, a despeito de usar premissa diversa da nossa, conclui de maneira semelhante:

\footnotetext{
não é aceitável, nem proporcional para o ordenamento processual civil a relativização e, muito menos, detém argumentação compatível com a teoria geral da prova, onde nela resta patenteada que não há espaço de verdade absoluta e, como conseqüência, de justiça absoluta.
}

Dessa forma, a impossibilidade de "relativizar-se" a coisa julgada, ainda que em casos supostamente excepcionais. Caso contrário, o sistema do direito positivo sofrerá nefastas consequiências em seu interior, causando ruídos prejudiciais, principalmente ao princípio da segurança jurídica.

Imagine-se, por exemplo, que um acórdão prolatado pelo Supremo Tribunal Federal tenha transitado em julgado, qual seria o órgão competente para "relativizar" a coisa julgada? O juiz de primeira instância? O Tribunal de segunda instância? Eis o ruído no sistema quando se tenta injetar nele variáveis por ele não albergadas ou permitidas: um sério problema de competência.

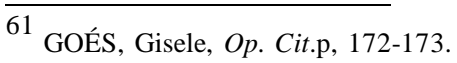


Não fora isso suficiente, imagine-se a "relativização" de determinada coisa julgada; a parte inicialmente vencedora e sobre a qual recaía a certeza de determinada conduta vai entender que sofreu outra injustiça-irrazoável, ou mesmo imoral. Essa parte poderá então relativizar a coisa julgada pela segunda vez? Não se perca de vista a lição de Ovídio A. Batista da Silva ${ }^{62}$ :

\footnotetext{
Que tribunal teria o poder de reconhecer essa injustiça, com força para impedir que outro tribunal, em julgamento subseqüiente - liberto da contingência da coisa julgada -, viesse a dizer, ao contrário do que dissera o segundo julgamento, que não houvera qualquer injustiça no primeiro julgamento; e muito menos uma "grave" injustiça?
}

O Código de Processo Civil de 2015 trouxe ruído ainda pior ao sistema: além de permitir essa intolerável desconstituição da coisa julgada, permitiu também que para isso caberia Ação Rescisória que teria um prazo iniciado em outro processo, no caso processo em trâmite no Supremo Tribunal Federal.

Hipótese tão nefasta quanto injurídica. Mais uma vez as premissas deste trabalho voltam para analisar essa tétrica mudança legislativa. Primeiro porque a Ação Rescisória é algo excepcionalssimo e deve ser utilizada apenas nas rigorosas hipóteses elencadas em lei; segundo porque permitir o ajuizamento de Ação Rescisória a algo futuro e incerto (na dependência de uma decisão do Supremo Tribunal Federal) viola flagrantemente o princípio da Segurança Jurídica e todo o arcabouço teórico neste trabalho soerguido.

\footnotetext{
62 SILVA, Ovídio A. Batista da. Coisa Julgada Relativa? in Relativização da Coisa Julgada, volume coletivo organizado por Fredie Didier Jr., Salvador (2. ed., 2 tiragem 2008) p. 312.
} 
Por fim, vale lembrar que o Superior Tribunal de Justiça, em recente decisão, afastou a possibilidade de relativizar a coisa julgada ${ }^{63} \mathrm{em}$ plena defesa do direito positivo. Afinal de contas, a coisa julgada encontra amparo constitucional ${ }^{64} \mathrm{e}$, sua defesa é premente, sob o risco de, desconsiderando-a fora dos estritos e rígidos contornos do direito, haver notória inconstitucionalidade. Por isso a afirmação: relativizar a coisa julgada é uma inconstitucionalidade!

\subsection{Inconstitucionalidade Notória do parágrafo 15 do artigo 525 do} Código de Processo Civil de 2015

Pode-se pensar, equivocadamente, ser o parágrafo 15 do artigo 525 do CPC/2015 a "positivação" da relativização da coisa julgada tida por inconstitucional.

Eis o que reza esse dispositivo legal:

§15: Se a decisão referida no $§ 12$ for proferida após o trânsito em julgado da decisão exequenda, caberá ação rescisória, cujo prazo será contado do trânsito em julgado da decisão proferida pelo Supremo Tribunal Federal.

\footnotetext{
63 Ação declaratória de nulidade de assento de registro de nascimento. Reconhecimento da paternidade em ação anterior transitada em julgado, dando ensejo ao registro agora impugnado.

1. Se o assento do registro civil decorre de decisão judicial transitada em julgado, não é possível modificá-lo sem que aquela seja desconstituída pela via processual própria.

2. Recurso especial não conhecido.

(REsp 435102/MG, Rel. Ministro CARLOS ALBERTO MENEZES DIREITO, TERCEIRA TURMA, julgado em 20/09/2005, DJ 13/02/2006 p. 79

64 Até mesmo DINAMARCO, Cândido Rangel, Relativizar a Coisa Julgada Material, in Revista de Processo n. 109, um dos principais defensores da tese da relativização da coisa julgada reconhece seu caráter constitucional, vide: "Na fórmula constitucional da garantia da coisa julgada está dito apenas que a lei não a prejudicará (art. 5, XXXVI), mas é notório que o constituinte minus dixit quam voluit, tendo essa garantia uma amplitude mais ampla do que as palavras poderiam fazer pensar. Por força da coisa julgada, não só o legislador carece de poderes para dar nova disciplina a uma situação concreta já definitivamente regrada em sentença irrecorrível, como também os juízes são proibidos de exercer a jurisdição outra vez sobre o caso e as partes já não dispõem do direito de ação ou de defesa como meios de voltar a veicular em juízo a matéria já decidida".
} 
Segundo esse dispositivo, ainda que a sentença tenha transitado em julgado e, no momento da execução, ou seja, já de posse de título executivo, houver declaração de inconstitucionalidade pelo Supremo Tribunal Federal ou mesmo fundado em aplicação ou interpretação da lei ou ato normativo tido por esse tribunal por incompatível com a Constituição da República Federativa do Brasil, poderá ser declarado inexigível aquele título arrimado em norma posteriormente julgada inconstitucional. Isso é possível? A segurança jurídica está aqui sendo preservada? E o que dizer do ordenamento jurídico? Mais uma vez aqui as premissas serão usadas como respostas a esses questionamentos.

É sabido, que, ao tempo em que formulada a norma individual e concreta havia norma jurídica (geral e abstrata) válida em um sistema de direito positivo (SDP1), em um tempo (T1). Ser uma norma válida significa que ela pertence a algum sistema jurídico. No presente caso, significa que ela pertence ao SDP1. Uma vez pertencente a um SDP jamais a norma deixará de pertencê-lo, como já explicado anteriormente.

Significa isso que, recaindo a coisa julgada em norma individual e concreta formulada com base em norma geral e abstrata em SDP1, arrimada com base em norma válida N1, no tempo T1, o fato de ser a norma abstrata e geral julgada inconstitucional pelo Supremo Tribunal Federal posteriormente a tal átimo, não poderá ser capaz de desfazer a coisa julgada formada em SDP1.

Como visto, uma vez pertencente a um Sistema do direito positivo a norma jamais deixará de pertencer ao ordenamento. Assim, se, no momento T1 havia norma abstrata e geral N1 válida e sobre esse foi formulada norma individual e concreta sobre a qual recaiu a coisa julgada, impossível será a desconstituição dessa última. Afinal de contas: a norma N1 jamais deixará de pertencer ao SDP1. Note-se o que leciona a respeito Barbosa Moreira ${ }^{65}$ :

A partir do trânsito em julgado, a norma concreta contida na sentença adquire, por assim dizer, vida própria e não é atingida pelas vicissitudes capazes de atingir a norma abstrata: nem é outra a razão pela qual, ainda que surta efeitos ex tunc, a declaração da inconstitucionalidade da lei não afeta a auctoritas rei iudIcatae da sentença que a tenha aplicado.

\footnotetext{
$\overline{65}$ Barbosa Moreira, Op. Cit. p. 253.
} 
No mesmo sentido, Luis Roberto Barroso ${ }^{66}$ :

sempre se considerou que o respeito às situações protegidas pela autoridade da res iudicata figurava como limite à retrospectividade do julgado, a menos que haja a possibilidade legítima de desconstituí-la por via da ação rescisória.

E continua:

o entendimento que prevalece na doutrina é o de que, transcorrido o prazo decadencial de dois anos para a propositura de ação rescisória, já não será mais possível desfazer a decisão, ainda quando se constate posteriormente sua inconstitucionalidade, salvo em se tratando de matéria penal.

Quer-se com isso respeitar a segurança jurídica: preceito constitucionalmente expresso no inciso XXXVI do artigo $5^{\circ}$ da Constituição da República Federativa do Brasil. A manter-se o dispositivo ora em voga, o ordenamento jurídico sofrerá ruído nefasto, provocando violação notória ao princípio da segurança jurídica. A declaração de sua inconstitucionalidade é de toda recomendável, portanto.

\section{CONSIDERAÇÕES FINAIS}

O direito como objeto cultural voltado à regulamentação das relações humanas não pode perpetuar seu percurso narrativo; as partes por ele reguladas não poderiam ficar ao alvedrio eterno de argumentos de justiça ou mesmo falta de razoabilidade ou proporcionalidade. Por isso criou um expediente jurídico para fazer a justiça formal: a coisa julgada.

É, por intermédio dela que se põe fim ao litígio e mantém-se a segurança jurídica na seara do direito. Pacifica-se o que passou e garante as atitudes futuras. É uma criação artificial do próprio direito positivo, o qual, é um sistema autopoiético autônomo das demais sistemas, motivo por que nele não podem entrar preceitos que não tenham sofrido a aprovação de seu próprio filtro jurídico interno.

\footnotetext{
${ }^{66}$ BARROSO, Luis Roberto. O Controle de Constitucionalidade no Direito Brasileiro, São Paulo, 2004, Saraiva, p. 167, 169.
} 
Por isso, a "relativização" da coisa julgada somente pode ocorrer nas estritas e excepcionais hipóteses pelo próprio direito positivo prescritas, sob o risco de criarem-se ruídos prejudiciais no interior do sistema do direito positivo que poderão "contaminá-

lo", como, por exemplo, problemas graves quanto à competência para se solicitar a "relativização" da coisa julgada e a eternização de novas "relativizações", por sempre o sucumbente entender haver sido injustiçado nas demandas.

Ainda que tenha havido uma tentativa de positivar-se a relativização da coisa julgada por intermédio do parágrafo 15 do artigo 525 do Código de Processo Civil 2015, essa manobra foi infeliz. Tentou-se com esses dispositivos destruir preceito de direito segundo o qual se deve aplicar ao fato a lei vigente à época de seu acontecimento. Sim, porque se ele busca desconstituir a coisa julgada que recaiu sobre a norma individual e concreta criada com amparo em norma geral e abstrata algum tempo depois declarada inconstitucional (a norma geral e abstrata) ele culmina por ferir de morte aquele preceito e, por conseqüência, fere frontalmente o princípio da segurança jurídica. Absolutamente inconstitucional, portanto.

Não se deve confundir, nesse caso, com as hipóteses restritas e taxativas para o cabimento da ação rescisória. Lá, houve vícios quando do momento da formação da norma individual e concreto que o direito positivo entende capaz de desconstituir a norma dada sua gravidade jurídica, como por exemplo, norma formulada por juiz subornado; por juiz impedido ou suspeito ou mesmo quando se fundar em prova falsa. Além disso, a Ação Rescisória não pode ficar condicionada a evento futuro e incerto.

Não: suas hipóteses são rígidas, excepcionais e previamente conhecidos. E mais: há um prazo pré-determinado para seu ajuizamento.

De se notar também, que todas essas hipóteses, referem-se a situações em que a norma foi constituída sob o vício existente à época de sua constituição e não sob condição de futuro entendimento de inconstitucionalidade de norma, de tal modo que o raciocínio mantém-se coerente: norma constituída em (T1), que não tenha sido formulada com os vícios taxativos da ação rescisória ou mesmo com vício de ausência de citação, jamais sairá do ordenamento e, portanto, uma declaração posterior de inconstitucionalidade não a retirará ordenamento jurídico. 


\section{REFERÊNCIAS}

BARBOSA MOREIRA, José Carlos. Considerações Sobre a Chamada "Relativização" da Coisa Julgada Material. In: Temas de direito processual - nona série. São Paulo: Saraiva, 2007, p. 235-265.

BARROSO, Luís Roberto. O Controle de Constitucionalidade no Direito Brasileiro. São Paulo: Saraiva, 2004.

BRASIL. Constituição da República Federativa do Brasil de 1988. Disponível em:<.http://www.planalto.gov.br/ccivil_03/constituicao/constituicaocompilado.htm>. Acesso em: 14 jan. 2015.

. Lei $\mathrm{n}^{\circ}$ 5.869, de 11 de janeiro de 1973. Institui o Código de Processo Civil. Disponível em:<http://www.planalto.gov.br/ccivil_03/leis/15869compilada.htm>. Acesso em: 14 jan. 2015.

. Supremo Tribunal Federal. CONSTITUCIONAL. PROCESSUAL.

MANDADO DE SEGURANÇA PREVENTIVO. SERVIDOR PÚBLICO: VANTAGEM DEFERIDA POR SENTENÇA JUDICIAL TRANSITADA EM JULGADO. TRIBUNAL DE CONTAS: DETERMINAÇÃO NO SENTIDO DA EXCLUSÃO DA VANTAGEM. COISA JULGADA: OFENSA. CF, art. 5 , XXXVI. I.

- A segurança preventiva pressupõe existência de efetiva ameaça a direito, ameaça que decorre de atos concretos da autoridade pública. Inocorrência, no caso, desse pressuposto da segurança preventiva. II. - Vantagem pecuniária, incorporada aos proventos de aposentadoria de servidor público, por força de decisão judicial transitada em julgado: não pode o Tribunal de Contas, em caso assim, determinar a supressão de tal vantagem, por isso que a situação jurídica coberta pela coisa julgada somente pode ser modificada pela via da ação rescisória. III. - Precedentes do Supremo Tribunal Federal. IV. Mandado de Segurança preventivo não conhecido. Mandado de Segurança conhecido e deferido relativamente ao servidor atingido pela decisão do TCU. (STF - MS: 25009 DF , Relator: Min. CARLOS VELLOSO, Data de Julgamento: 24/11/2004, Tribunal Pleno, Data de Publicação: DJ 29-04-2005 PP-00008 EMENT VOL02189-02 PP-00229 LEXSTF v. 27, n. 319, 2005, p. 135-150 RTJ VOL-00194-02 PP-00594)

. Superior Tribuna de Justiça. Ação declaratória de nulidade de assento de registro de nascimento. Reconhecimento da paternidade em ação anterior transitada em julgado, dando ensejo ao registro agora impugnado. 1. Se o assento do registro civil decorre de decisão judicial transitada em julgado, não é possível modificá-lo sem que aquela seja desconstituída pela via processual própria. 2. Recurso especial não conhecido. STJ - REsp: 435102 MG 2002/0057659-2, Relator: Ministro CARLOS ALBERTO 
MENEZES DIREITO, Data de Julgamento: 20/09/2005, T3 - TERCEIRA TURMA, Data de Publicação: DJ 13/02/2006 p. 792.

CARVAlHO, Paulo de Barros. Curso de Direito Tributário. 25. ed. rev. São Paulo: Saraiva, 2013.

. Direito Tributário: fundamentos jurídicos da incidência. 2. ed. rev. São Paulo:

Saraiva, 1999.

- A Prova no Procedimento Administrativo Tributário. In: Revista Dialética de

Direito Tributário, n. 34 jul, São Paulo, p. 104-116.

. Princípio da Segurança Jurídica em Matéria Tributária. In: Revista de Direito

Tributário, n. 61, São Paulo, p. 74-90.

. Segurança Jurídica e Modulação dos Efeitos. In: Revista de Direito

Tributário, n. 102, São Paulo, p. 18-28.

DE SANTI, Eurico Marcos Diniz; CONRADO, Paulo Cesar. Controle Direito de Constitucionalidade e Repetição do Indébito Tributário, In: Revista Dialética de Direito Tributário, n. 86, São Paulo, p. 27-33.

DELGADO, José Augusto. Efeitos da Coisa Julgada e os Princípios Constitucionais, In: NASCIMENTO, Carlos Valder do (coord.) Coisa Julgada Inconstitucional, 3. ed. Rio de Janeiro: América Jurídica, 2003.

DINAMARCO, Cândido Rangel. Relativizar a Coisa Julgada Material, In: Revista de Processo, n. 109, São Paulo, p. 9-37. GÓES, Gisele Santos Fernandes. A "Relativização" da Coisa Julgada: Exame Crítico (Exposição de um Ponto de Vista Contrário) In: DIDIER JR., Fredie (org.) Relativização da Coisa Julgada, 2 ed., 2 tiragem. Salvador: JusPODIVM, 2008.

MORESO, José Juan. Lenguaje jurídico. In: El derecho y la justicia. 2. ed. Madrid: Trotta, 2000.

KELSEN, Hans. Teoria pura do direito. 6. ed., $4^{\text {a }}$ tiragem. São Paulo: Martins Fontes, 2000 .

MACEDO, Alexander dos Santos. Da Querela Nullitatis Sua Subsistência no Direito Brasileiro. 3. ed. Rio de Janeiro: Lumen Juris, 2005.

MOUSSALLEM, Tárek Moysés. Revogação em Matéria Tributária. São Paulo: Noeses, 2005.

. Fontes do Direito Tributário. In: Curso de Especialização em Direito

Tributário, Rio de Janeiro: Forense, 2005.

Função das súmulas e critérios para aferir sua validade, vigência e aplicabilidade. Inédita, 2005.

Fontes do direito tributário. São Paulo: Max Limonad, 2001.

Revista de Teorias do Direito e Realismo Jurídico | e-ISSN: 2525-9601 | Minas Gerais | v. 1 | n. 2 | p. 208 - 241| Jul/Dez. 2015. 
NERY JUNIOR, Nelson. Coisa Julgada e o Estado Democrático de direito, In: Revista Forense, v. 375, p. 141-159.

PINHO, Alessandra Gondim. Fato jurídico tributário. São Paulo: Noeses, 2001.

ROBLES, Gregório. O direito como texto. São Paulo: Manole, 2005.

SICHES, Rechásens. Tratado de Sociologia. 1. ed. $3^{\text {a }}$ impr. Vol. I e II, Porto Alegre: Editora Globo, 1970. 2006. p. 27. SICHES, Luis Recásens, Introducción al estudio del derecho. México: Porruá,

SILVA, Ovídio A. Batista da. Coisa Julgada Relativa? In: Relativização da Coisa Julgada. Volume coletivo organizado por Fredie Didier Jr., Salvador (2. ed., 2 tiragem, 2008).

TEUBNER, Gunter, O Direito como Sistema Autopoiético. Lisboa: Fundação Calouste Gulbenkian, 1993.

THEODORO JUNIOR, Humberto; FARIA, Juliana Cordeiro de. A Coisa Julgada Inconstitucional e os Instrumentos Processuais para seu Controle, In: Revista dos Tribunais, v. 795, p. 21-40.

TOME, Fabiana Del Padre, A prova no Direito Tributário, São Paulo, Noeses, 2005. O Sistema Autopoiético do Direito e suas Implicações em Relação à Segurança Jurídica, In: Revista de Direito Tributário, n. 104, São Paulo, p. 86-94.

URBAN. Wilbur Marshall. Lenguaje y realidad: la filosofía del lenguaje y los principios del simbolismo. Trad. Carlos Villegas y Jorge Portilla. México/Buenos Aires: 1952.

VALVERDE, Gustavo Sampaio. Coisa Julgada em Matéria Tributária. São Paulo: Quartier Latin, 2004.

VILANOVA, Lourival. Sobre o conceito de direito. In: VILANOVA, Lourival. Escritos Jurídicos e Filosóficos. V. 1. São Paulo: IBET/Axis Mundi, 2003. 
Níveis de Linguagem em Kelsen: norma jurídica/proposição jurídica. São Paulo. In: VILANOVA, Lourival. Escritos Jurídicos e Filosóficos. V. 2. São Paulo: IBET/Axis Mundi, 2003.

Analítica do dever-ser. In: VILANOVA, Lourival. Escritos jurídicos e

filosóficos. São Paulo: Axis Mundi, 2003. v. 2. p. 69.

As estruturas lógicas e o sistema do direito positivo. 3. ed. São Paulo:

Noeses,

2005. 
